\title{
EVALUATION OF WATER QUALITY INDEX OF WATER BODIES CHANNARAYAPATNA TALUK, KARNATAKA REGION, INDIA
}

\author{
H. R. Bharathi ${ }^{1}$, S. Manjappa ${ }^{2 *}$, T. Suresh ${ }^{3}$ and B. Suresh ${ }^{4}$ \\ ${ }^{1}$ Department of Environmental Science Kuvempu University, Shankaraghatta, Shimoga, Karnataka, India. \\ ${ }^{2}$ Dept. of Chemistry, University BDT College of Engineering, Davangere - 577005, Karnataka, India. \\ ${ }^{3}$ Department of Chemistry, Vijayanagara Sri Krishnadevaraya University, Bellary-583104, Karnataka, India \\ ${ }^{4}$ Department of Civil Engineering, Bapuji Institute of Engineering \& Technology, Davangere - 577 004, Karnataka, India. \\ *Corresponding author's email: drsmubdtce@rediffmail.com
}

\begin{abstract}
Present communication deals with a study of Physico-chemical parameters such as pH, Temperature, Total Suspended Solids, Turbidity, Dissolved Oxygen, Biochemical Oxygen Demand, Nitrate and Phosphate in water samples of Channarayapatna, Janivara, Anekere and Baghur water bodies in Channarayapatna taluka, Karnataka state of India. The water quality of the samples was compared with standard values given by World Health Organization (WHO) and United State Salinity Laboratory for drinking and irrigation purposes. Water Quality Index (WQI) was also calculated to know the overall quality of water samples. Water quality index (WQI) of Surface water body of various Sampling locations of Channarayapatna taluka, Karnataka ranged between 61.82 and 68.27 indicates the fair quality of water. The water quality index is calculated by indicator (100-point scale) shows that water is suitable for drinking purposes only after pretreatment like filtering, boiling, reverse osmosis and electro dialysis. WQI can play a big role in justifying the water pollution problems after encountered in different surface water bodies. Application of Water Quality Index (WQI) in this study has been found useful in assessing the overall quality of water and to get ride of judgment on quality of the surface water.
\end{abstract}

Keywords: Water Quality Index; surface water bodies; Channarayapatna; Region

\section{Introduction}

The term "water quality" includes the water column and the physical channel required to sustain aquatic life. The goal of the federal Clean Water Act, "To protect and maintain the chemical, physical and biological integrity of the nation's waters," establishes the importance of assessing both water quality and the habitat required for maintaining other aquatic organisms. Water, the precious gift of nature to human being, is going to be polluted day-by-day with increasing urbanization.

It is well known fact that potable safe water is absolutely essential for healthy living. Adequate supply of fresh and safe drinking water is a basic need for all human beings on the earth. The problem of drinking water contamination, water conservation and water quality management has assumed a very complex shape. Attention on water contamination and its management has become a need of our because of far reaching impact on human health. The major hazard in drinking water supplies is microbial contamination, which is due to agricultural land wash, domestic sewage, industrial effluents, improper storage and handling (WHO, 2006; Saha et al., 2006).

The use of water quality indices (WQI) is a simple practice that overcomes many of the previous mentioned problems and allows the public and decision makers to receive water quality information (AOAC) (1995). The major tool of pollution profile studies is the water quality index (WQI). Horton proposed the first formal WQI in the literature in 1965 (Ott, 1978).Water Quality Index (WQI) is regarded as one of the most effective way to communicate water quality (Kannan, 1991; Pradhan, et al., 2001). In a number of nationwide studies, water quality of different natural resources was assessed on the basis of calculated water quality indices (Sinha, et al., 2001; Rajmohan, 2003). The data obtained through quantitative analysis and WHO water quality standards8 were used for calculating water quality indices. The purpose of calculating WQI and comparing it with the standards is to assess drinking water contamination 
at selected water body at Channarayapatna taluka and seasonal variation of water quality after the onset of monsoon on the basis of calculated values of water quality indices.

A water quality index is a means to summarize large amounts of water quality data into simple terms for reporting to management and the public in a consistent manner. Similar to the UV index or an air quality index, it can tell us whether the overall quality of water bodies possess a potential threat to various uses of water, such as habitat for aquatic life, irrigation water for agriculture and livestock, recreation and aesthetics, and drinking water supplies. Water quality index (WQI) is a single value indicator to the water quality. It integrates the data pool generated after collecting due weights to the different parameters.

\section{Material and Methods}

\section{Study Area}

The study was carried out at selected water body in Channarayapatna taluk, which are a balancing and maintained to serve water requirement for irrigation and other human activity. The water samples from the identified water bodies were collected at an interval of 30 days and analyzed for 14 physico-chemical parameters as per the standard method (APHA, 1989). The study area is shown on a satellite image with 4 sampling stations. The present study was conducted along the priority road which is of 18 $\mathrm{Kms}$ in length, touching 4 villages (water body) namely Channarayapatna, Janivara, Bagura and Anekere. The Latitude and longitude ranges given in Table 1. Water quality index is calculated to determine the suitability of water for drinking purposes (Srivastava and Sinha, 1994; Das et al., 2001; Joshi, et al., 2004; Bhoi, et al., 2005). Water sampling index in is given in Fig. 1.

Table 1: Surface Water Sampling Locations in Channarayapatna taluk, Karnataka

\begin{tabular}{|l|l|l|l|}
\hline $\begin{array}{l}\text { S. } \\
\text { N. }\end{array}$ & $\begin{array}{l}\text { Code \& Name of } \\
\text { the site }\end{array}$ & Longitude & Latitude \\
\hline 1 & $\mathrm{SC}_{1}$ & $76^{\circ} 24^{\prime} 30.5$ & $12^{\circ} 54^{\prime} 56.9$ \\
& $\mathrm{Channarayapatna}^{\prime \prime} \mathrm{E}$ & $7^{\prime \prime} \mathrm{N}$ \\
\hline 2 & $\mathrm{SB}_{1}$ Bagur & $76^{\circ} 23^{\prime} 35.1$ & $13^{\circ} 01^{\prime} 23.2$ \\
& & $2^{\prime \prime} \mathrm{E}$ & $5^{\prime \prime} \mathrm{N}$ \\
\hline 3 & $\mathrm{SJ}_{1}$ Janivara & $76^{\circ} 25^{\prime} 37.6$ & $12^{\circ} 53^{\prime} 33.7$ \\
& & $6^{\prime \prime} \mathrm{E}$ & $6^{\prime \prime} \mathrm{N}$ \\
\hline 4 & $\mathrm{SA}_{1}$ Anekere & $76^{\circ} 20^{\prime} 52.1$ & $12^{\circ} 54^{\prime} 30.4$ \\
& & $2^{\prime \prime} \mathrm{E}$ & $7^{\prime \prime} \mathrm{N}$ \\
\hline
\end{tabular}

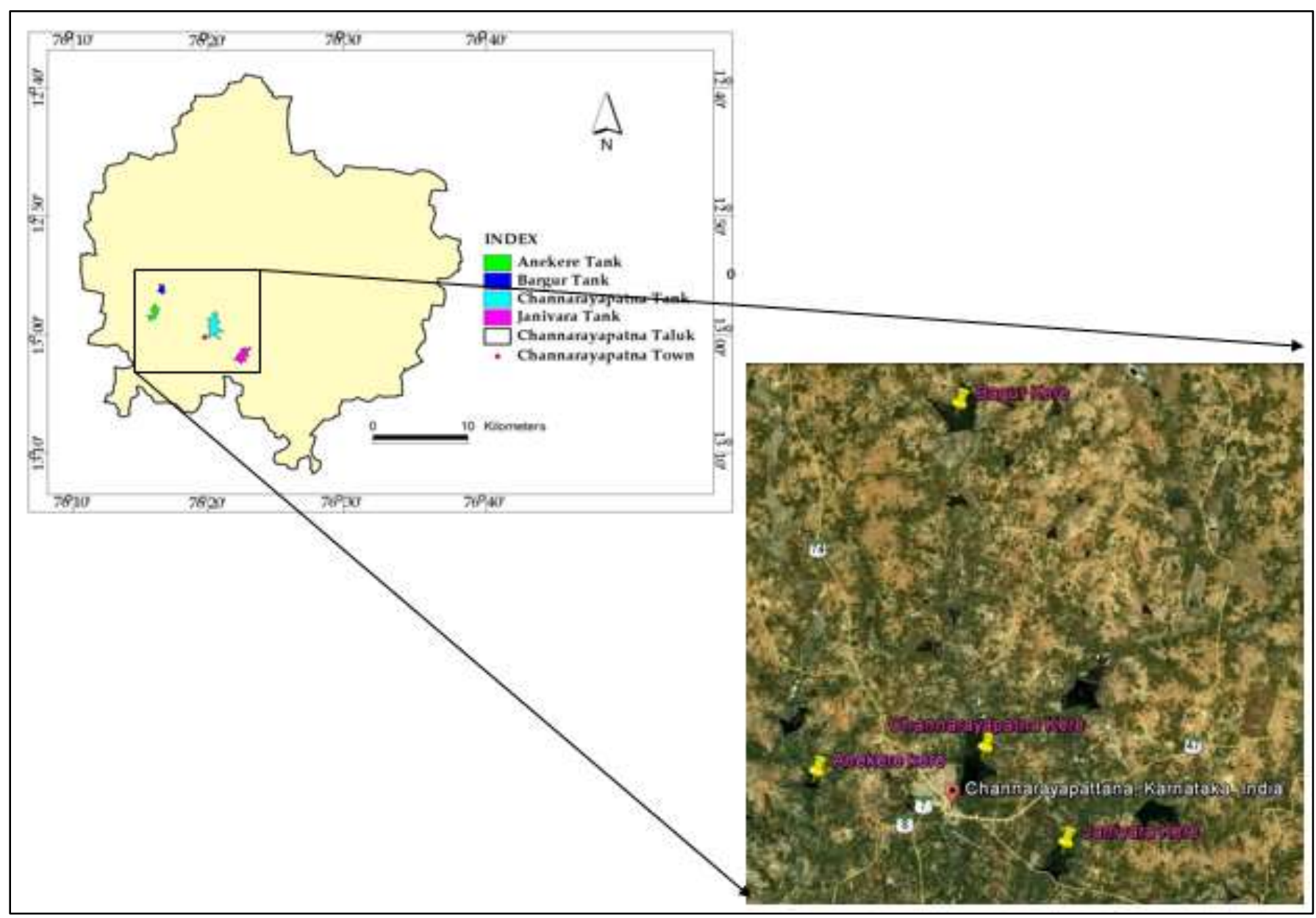

Fig. 1: Index of sampling location in Channarayapatna Taluk 


\section{Laboratory Analysis}

In order to determine the water quality index, surface water samples were collected at selected water body from two sampling sites at each water body during June 2010 to January 2011. The samples were collected in sterilized bottles using the standard procedure for grab samples in accordance with standard methods of (Ramakrishniah, C.R., et al., 2009). The samples were analyzed as per standard methods for thirteen Physico-Chemical parameters namely; pH (Hydrogen ion concentration), Turbidity, EC (Electrical conductivity), TDS (Total Dissolved Solids), TS(Total Solids), DO (Dissolved oxygen), BOD (Biochemical Oxygen Demand) and COD (Chemical Oxygen Demand), , TH (Total hardness), Total Alkalinity (TA) ions of $\mathrm{Ca}^{2+}$ (Calcium), $\mathrm{NO}_{3}$ (Nitrate) and $\mathrm{Cl}^{-}$ (chloride), and Phosphate $\left(\mathrm{PO}_{4}\right)$. In situ measurement was adopted to determine unstable parameters including; $\mathrm{pH}$, EC and DO by portable meters. The analysis of the parameters total hardness and ions of each calcium, magnesium, chloride and Free $\mathrm{CO}_{2}$ were carried out by volumetric analysis in accordance with standard methods of (Ramakrishniah, C.R., et al., 2009).

\section{Calculation of WQI}

The Water Quality Index (WQI) was calculated using the Weighted Arithmetic Index method. The quality rating scale for each parameter qi was calculated by using this expression (Sinha, D. K., et al., 2004).

Quality rating, Qi = $100[(\mathrm{Vn}-\mathrm{Vi}) /(\mathrm{Vs}-\mathrm{Vi})]$

Where, Vn: actual amount of nth parameter

Vi: the ideal value of this parameter

$\mathrm{Vi}=0$, except for $\mathrm{pH}$ and $\mathrm{DO} . \mathrm{Vi}=7.0$ for $\mathrm{pH} ; \mathrm{Vi}=$ $14.6 \mathrm{mg} / \mathrm{L}$ for DO.

Vs: recommended WHO standard of corresponding parameter

Relative weight (Wi) was calculated by a value inversely proportional to the recommended standard $(\mathrm{Si})$ of the corresponding parameter.

$\mathrm{Wi}=1 / \mathrm{Si}$, WQI are discussed for a specific and intended use of water. In this study the WQI for human consumption is considered and permissible WQI for the drinking water is taken as 100. The overall WQI was calculated by using Equation:

Water Quality Index (WQI) $=\Sigma(\mathrm{Qi}) \mathrm{Wi} / \Sigma \mathrm{Wi}(\mathrm{WQI})$

\section{Results and Discussion}

Physico-chemical characteristics of Surface water quality at four region of Channarayapatna, Janivara, Bagur and Anekere water body at Channarayapatna Taluk of Karnataka state are given from Tables 2 to 5 respectively. It should be recognized that, like dissolved oxygen, $\mathrm{pH}$ varies naturally due to the photosynthesis and respiration cycles in the presence of algae in Channarayapatna water body. The $\mathrm{pH}$ is measure of the intensity of acidity or alkalinity and the concentration of hydrogen ion concentration. $\mathrm{pH}$ has no direct adverse effects on health; however, higher values of $\mathrm{pH}$ hasten the scale formation in water heating apparatus and also reduce germicidal potential of chloride. The $\mathrm{pH}$ values of water samples of present study ranged from 7.17 (south region) to 7.40 (north region) for Channarayapatna, 7.03 (east region) to 7.55 (south region) for Bagur, 7.40 (north region) to 7.60 (north region) for Janivara and 7.14 (west region to 7.56 (north region) for Anekere water bodies respectively. These values are within the prescribed limit of standards (WHO 2001; 2002). The analyses of the parameters, their range, mean and SD compared with WHO standards are given in respective Tables. Turbidity in selected surface water body samples of Channarayapatna, Bagur, Janivara and Anekere ranged from 2.18 NTU at west region of the Channarayapatna water body to 5.01 NTU in north region of Bagur water body respectively. Electrical conductivity (EC) content in water samples of selected water body (Channarayapatna, Bagur, Janivara and Anekere) ranged from $342.0 \mathrm{mS} / \mathrm{cm}$ to $724.0 \mathrm{mS} / \mathrm{cm}$ at East and south regions og Bagur and Channarayapatna water body. The results show that EC values high in Channarayapatna and low in Bagur. Prescribed standard values by WHO for EC is $1400 \mathrm{mS} / \mathrm{cm}$. The value of EC is very low $(342.0 \mathrm{mS} / \mathrm{cm})$ in the water of Bagur water body.

Total suspended solids (TSS) are found in natural surface water. TSS values of water samples ranged from 1.0 to 4.2 $\mathrm{mg} / \mathrm{L}$. The SD values of TSS for water samples of selected water body of Channarayapatna Taluka Karnataka region, Channarayapatna, Bagur, Janivara and Anekere are \pm 0.93 , $\pm 1.18, \pm 0.68$ and \pm 0.25 respectively. Maximum TDS of well water found in Abbottabad district having value of the $556 \mathrm{mg} / \mathrm{L}$ in Channarayapatna water body, while the minimum TDS value was found to be $239 \mathrm{mg} / \mathrm{L}$ in Janivara water body (Table 2). The result showed that the drinking water of selected water bodies from Channarayapatna taluk is fit for drinking in terms of TDS.

The classification of groundwater, based on total hardness shows that no on water samples from selected water bodies in channarayapatna fall in the within the permissible limit of WHO, BIS and ICMR category. The maximum allowable limit of total hardness is $500 \mathrm{mg} / \mathrm{l}$ and the most desirable limit is $300 \mathrm{mg} / \mathrm{l}$ as per the WHO, BIS and ICMR standards (Table 2). For total hardness, the most desirable limit is $80 \mathrm{mg} / \mathrm{L}$ to $100 \mathrm{mg} / \mathrm{L}$ Hardness below $300 \mathrm{mg} / \mathrm{l}$ is considered potable but beyond this limits cause gastrointestinal irritation (ICMR 1975). Normal water hardness does not pose any direct health problems. Jain et.al 1998 reported that high concentration of hardness (150 to 300 $\mathrm{mg} / \mathrm{l}$ and above) May cause kidney problems. From the study it reveals that all the selected water bodies were showing the hardness content is within the permissible limit 
of drinking water standards. Calcium and Magnesium content in selected water bodies samples were found within the permissible limit given by WHO standards $(75 \mathrm{mg} / \mathrm{l})$ except Channarayapatna and Janivara which is very near to the source of Agricultural runoff. The value of SD of calcium and magnesium of water samples is for Channarayapatna, Bagur, Janivara and Anekere water bodies are computed as $\pm 12.10, \pm 13.79, \pm 5.10, \pm 5.14$ and $\pm 6.75, \pm 8.27, \pm 2.45$ and \pm 2.31 respectively.

Table 2: Drinking water Standards of WHO (1963), BIS (1992) and ICMR (1975)

\begin{tabular}{|l|l|l|l|}
\hline Parameters & WHO & BIS & ICMR \\
\hline $\mathrm{pH}$ & $\begin{array}{l}6.5- \\
8.5\end{array}$ & $\begin{array}{l}7.0- \\
8.0\end{array}$ & $7.0-8.5$ \\
\hline $\begin{array}{l}\text { Electrical Conductivity, } \\
\mu \mathrm{s} / \mathrm{cm}\end{array}$ & 3000 & 3000 & 3000 \\
\hline Total Hardness, ppm & 500 & 500 & 300 \\
\hline Calcium hardness, ppm & 75 & 75 & 75 \\
\hline Magnesium, ppm & 50 & 50 & 50 \\
\hline Chloride, ppm & 250 & 200 & $250-$ \\
\hline Alkalinity, ppm & 75 & --- & 1000 \\
\hline Dissolved Oxygen, ppm & $4.0-$ & $4.0-$ & $4.0-6.0$ \\
& 6.0 & 6.0 & \\
\hline Nitrate & 20 & 45 & -- \\
\hline BOD & 5 & -- & -- \\
\hline DO & $>5$ & -- & -- \\
\hline Turbidity & 10 & 5 & -- \\
\hline Total Suspended Solids & 0 & -- & -- \\
\hline TDS & 2000 & -- & -- \\
\hline
\end{tabular}

The alkalinity range set by WHO is $500 \mathrm{mg} / \mathrm{L}$. The result on alkalinity of water samples from selected water bodies showing the alkalinity found 232.50, 248.25, 179.0 and $188.25 \mathrm{mg} / \mathrm{L}$. Minimum alkalinity found in Janivara water body was $179.0 \mathrm{mg} / \mathrm{L}$ (Table 4 ). The maximum range of alkalinity is $232.5 \mathrm{mg} / \mathrm{L}$ (Table 3). Free Carbon Dioxide content of water samples of channarayapatna taluk, Hassan district of Karnataka ranged from $2.3 \mathrm{mg} / \mathrm{L}$ at east region to 3.4 at south region in channarayapatna, $1.2 \mathrm{mg} / \mathrm{L}$ north region to $2.6 \mathrm{mg} / \mathrm{L}$ in Bagur, $0.9 \mathrm{mg} / \mathrm{L}$ to $2.6 \mathrm{mg} / \mathrm{L}$ in Janivara and $0.6 \mathrm{mg} / \mathrm{L}$ to $2.1 \mathrm{mg} / \mathrm{L}$ in Anekere water body respectively. The value of $\mathrm{SD}$ of free carbon dioxide of water samples is for Channarayapatna, Bagur, Janivara and Anekere computed as $( \pm 0.46, \pm 0.59, \pm 0.74$ and \pm 0.62$)$. Chloride: Chloride values ranged from $17.89 \mathrm{mg} / \mathrm{L}$ at south region of Janivara water body to $85.18 \mathrm{mg} / \mathrm{L}$ at south region of channarayapatna water body. High chloride content can cause high blood pressure in people. Chloride in excess $(<250 \mathrm{mg} / \mathrm{l})$ imparts a salty taste to water and people who are not accustomed to high chloride may be subjected to laxative effect. High Chloride concentration is also an indicator of large amount of organic matter. Present study reveals that all the water bodies were showing the chloride content within the permissible limit of prescribed standards. Dissolved oxygen concentration of selected water bodies ranged from $5.20 \mathrm{mg} / \mathrm{L}$ to $6.36 \mathrm{mg} / \mathrm{L}$ in Channarayapatna water body, while in Bagur water body $5.40 \mathrm{mg} / \mathrm{L}$ to 7.40 $\mathrm{mg} / \mathrm{L}$. Janivara water body is ranged from $6.32 \mathrm{mg} / \mathrm{L}$ to 8.10 $\mathrm{mg} / \mathrm{L}$ and in Anekere water body is $6.5 \mathrm{mg} / \mathrm{L}$ to $7.98 \mathrm{mg} / \mathrm{L}$ of Hassan District, Karnataka. All water samples of Karnataka Hassan region were found within the permissible limit given by WHO, BIS and ICMR. The SD values of DO in water samples is for Channarayapatna, Bagur, Janivara and Anekere computed as $\pm 0.59, \pm 0.89, \pm 0.73$ and \pm 1.59 respectively). The scope of parameters is limited to evaluation indicators or criteria that are representative of the type of pollution. BOD and COD both parameters are interdepended at the ration of 1:3. From the present also reveals the same trend. The average BOD content of water samples of Channarayapatna, Bagur, Janivara and Anekere water body are 6.0, 3.61, 3.02 and $3.67 \mathrm{mg} / \mathrm{L}$. The average COD content of water samples of Channarayapatna, Bagur, Janivara and Anekere water body are 14.93, 10.50, 9.0 and $9.55 \mathrm{mg} / \mathrm{L}$ respectively. Except channarayapatna water body, all other three water bodies of Hassan District Karnataka State was found within the permissible limit given by WHO; BOD $5 \mathrm{mg} / \mathrm{l}\left(5\right.$ days at $\left.20^{\circ} \mathrm{C}\right)$.

Table 3: Physico-chemical characteristics of surface water of Channarayapatna Water body

\begin{tabular}{|l|l|l|l|l|l|l|l|}
\hline Parameters & $\begin{array}{l}\text { North } \\
\text { region }\end{array}$ & $\begin{array}{l}\text { South } \\
\text { region }\end{array}$ & $\begin{array}{l}\text { East } \\
\text { region }\end{array}$ & $\begin{array}{l}\text { West } \\
\text { region }\end{array}$ & Mean & SD & $\begin{array}{l}\text { Comparison with } \\
\text { WHO standard }\end{array}$ \\
\hline $\mathrm{pH}$ & 7.40 & 7.17 & 7.30 & 7.27 & 7.29 & 0.09 & within \\
\hline Turbidity & 2.40 & 3.08 & 2.20 & 2.18 & 2.47 & 0.42 & within \\
\hline $\begin{array}{l}\text { Conductivity, } \\
\mu \text { s/cm }\end{array}$ & 612.0 & 724.0 & 422.0 & 642.0 & 600.00 & 127.76 & within \\
\hline $\begin{array}{l}\text { Total Alkalinity, } \\
\text { ppm }\end{array}$ & 175.0 & 240.0 & 275.0 & 240.0 & 232.50 & 41.73 & exceed \\
\hline $\begin{array}{l}\text { Total Suspended } \\
\text { Solids, ppm }\end{array}$ & 4.2 & 3.6 & 2.7 & 2.1 & 3.15 & 0.93 & exceed \\
\hline
\end{tabular}


H.R. Bharathi et al. (2016) Int J Appl Sci Biotechnol, Vol 4(4): 475-482

Table 3: Physico-chemical characteristics of surface water of Channarayapatna Water body

\begin{tabular}{|l|l|l|l|l|l|l|l|}
\hline Parameters & $\begin{array}{l}\text { North } \\
\text { region }\end{array}$ & $\begin{array}{l}\text { South } \\
\text { region }\end{array}$ & $\begin{array}{l}\text { East } \\
\text { region }\end{array}$ & $\begin{array}{l}\text { West } \\
\text { region }\end{array}$ & Mean & SD & $\begin{array}{l}\text { Comparison with } \\
\text { WHO standard }\end{array}$ \\
\hline TDS, ppm & 581.0 & 671.0 & 481.0 & 491.0 & 556.00 & 88.88 & exceed \\
\hline DO, ppm & 6.22 & 6.36 & 5.20 & 5.36 & 5.79 & 0.59 & Medium \\
\hline BOD, ppm & 5.42 & 5.97 & 6.20 & 6.42 & 6.00 & 0.43 & Within \\
\hline COD, ppm & 16.86 & 15.00 & 12.86 & 15.00 & 14.93 & 1.63 & --- \\
\hline Total hardness, ppm & 170.0 & 150.0 & 160.0 & 130.0 & 152.50 & 17.08 & Within \\
\hline Calcium, ppm & 60.92 & 64.13 & 56.92 & 84.13 & 66.53 & 12.10 & medium \\
\hline Magnesium, ppm & 36.81 & 34.34 & 34.71 & 30.24 & 32.03 & 6.75 & Within \\
\hline Free $\mathrm{CO}_{2}, \%$ & 2.8 & 3.4 & 2.3 & 2.6 & 2.78 & 0.46 & -- \\
\hline Chloride, ppm & 71.57 & 85.18 & 51.97 & 69.18 & 69.48 & 13.63 & within \\
\hline
\end{tabular}

Table 4: Physico-chemical characteristics of surface water of Bagur Water body

\begin{tabular}{|l|l|l|l|l|l|l|l|}
\hline Parameters & $\begin{array}{l}\text { North } \\
\text { region }\end{array}$ & $\begin{array}{l}\text { South } \\
\text { region }\end{array}$ & $\begin{array}{l}\text { East } \\
\text { region }\end{array}$ & $\begin{array}{l}\text { West } \\
\text { region }\end{array}$ & Mean & SD & $\begin{array}{l}\text { Comparison with } \\
\text { WHO standard }\end{array}$ \\
\hline $\mathrm{pH}$ & 7.07 & 7.55 & 7.03 & 7.28 & 7.23 & 0.24 & within \\
\hline Turbidity & 5.10 & 2.80 & 3.40 & 3.18 & 3.62 & 1.02 & within \\
\hline Conductivity, $\mu \mathrm{s} / \mathrm{cm}$ & 560.0 & 536.0 & 342.0 & 442.0 & 470.00 & 99.37 & within \\
\hline $\begin{array}{l}\text { Total Alkalinity, } \\
\text { ppm }\end{array}$ & 240.0 & 190.0 & 265.0 & 298.0 & 248.25 & 45.52 & exceed \\
\hline $\begin{array}{l}\text { Total Suspended } \\
\text { Solids, ppm }\end{array}$ & 2.9 & 2.2 & 1.0 & 3.8 & 2.48 & 1.18 & exceed \\
\hline TDS, ppm & 320.0 & 304.0 & 260.0 & 160.0 & 261.00 & 71.95 & within \\
\hline DO, ppm & 6.00 & 7.40 & 5.40 & 5.66 & 6.12 & 0.89 & Medium \\
\hline BOD, ppm & 3.52 & 4.51 & 3.80 & 2.62 & 3.61 & 0.78 & Within \\
\hline COD, ppm & 7.26 & 14.60 & 11.00 & 9.12 & 10.50 & 3.13 & --- \\
\hline Total hardness, ppm & 280.0 & 250.0 & 260.0 & 230.0 & 255.00 & 20.82 & Within \\
\hline Calcium, ppm & 85.09 & 64.47 & 52.13 & 62.62 & 66.08 & 13.79 & Within \\
\hline Magnesium, ppm & 33.12 & 25.19 & 44.71 & 30.24 & 33.32 & 8.27 & Within \\
\hline Free CO,$\%$ & 1.8 & 1.2 & 2.1 & 2.6 & 1.93 & 0.59 & -- \\
\hline Chloride, ppm & 59.7 & 21.87 & 34.50 & 40.32 & 39.10 & 15.75 & within \\
\hline
\end{tabular}

Table 5: Physico-chemical characteristics of surface water of Janivara Water body

\begin{tabular}{|l|l|l|l|l|l|l|l|}
\hline Parameters & $\begin{array}{l}\text { North } \\
\text { region }\end{array}$ & $\begin{array}{l}\text { South } \\
\text { region }\end{array}$ & $\begin{array}{l}\text { East } \\
\text { region }\end{array}$ & $\begin{array}{l}\text { West } \\
\text { region }\end{array}$ & Mean & SD & $\begin{array}{l}\text { Comparison with } \\
\text { WHO standard }\end{array}$ \\
\hline $\mathrm{pH}$ & 7.60 & 7.59 & 7.40 & 7.59 & 7.55 & 0.10 & within \\
\hline Turbidity & 2.90 & 3.10 & 2.70 & 2.80 & 2.88 & 0.17 & within \\
\hline Conductivity, $\mu \mathrm{s} / \mathrm{cm}$ & 589.0 & 489.0 & 643.0 & 369.0 & 522.50 & 120.59 & within \\
\hline Total Alkalinity, ppm & 170.0 & 185.0 & 192.0 & 169.0 & 179.00 & 11.34 & exceed \\
\hline Total Suspended Solids, ppm & 2.4 & 3.2 & 2.8 & 1.6 & 2.50 & 0.68 & exceed \\
\hline
\end{tabular}


H.R. Bharathi et al. (2016) Int J Appl Sci Biotechnol, Vol 4(4): 475-482

Table 5: Physico-chemical characteristics of surface water of Janivara Water body

\begin{tabular}{|l|l|l|l|l|l|l|l|}
\hline Parameters & $\begin{array}{l}\text { North } \\
\text { region }\end{array}$ & $\begin{array}{l}\text { South } \\
\text { region }\end{array}$ & $\begin{array}{l}\text { East } \\
\text { region }\end{array}$ & $\begin{array}{l}\text { West } \\
\text { region }\end{array}$ & Mean & SD & $\begin{array}{l}\text { Comparison with } \\
\text { WHO standard }\end{array}$ \\
\hline TDS, ppm & 290.0 & 260.0 & 210.0 & 196.0 & 239.00 & 43.71 & within \\
\hline DO, ppm & 7.20 & 7.32 & 8.10 & 6.32 & 7.24 & 0.73 & Medium \\
\hline BOD, ppm & 3.50 & 2.67 & 2.80 & 3.12 & 3.02 & 0.37 & Within \\
\hline COD, ppm & 10.00 & 6.00 & 12.00 & 8.00 & 9.00 & 2.58 & --- \\
\hline Total hardness, ppm & 176.0 & 152.0 & 166.0 & 148.0 & 160.50 & 12.90 & Within \\
\hline Calcium, ppm & 44.09 & 38.48 & 42.09 & 32.48 & 39.29 & 5.10 & Within \\
\hline Magnesium, ppm & 16.08 & 13.65 & 18.08 & 12.65 & 15.12 & 2.45 & Within \\
\hline Free $\mathrm{CO}_{2}, \%$ & 2.6 & 0.9 & 1.5 & 1.2 & 1.55 & 0.74 & -- \\
\hline Chloride, ppm & 29.82 & 17.89 & 19.82 & 16.92 & 21.11 & 5.93 & within \\
\hline
\end{tabular}

Table 6: Physico-chemical characteristics of surface water of Anekere Water body

\begin{tabular}{|l|c|c|c|c|c|c|c|}
\hline \multicolumn{1}{|c|}{ Parameters } & $\begin{array}{c}\text { North } \\
\text { region }\end{array}$ & $\begin{array}{c}\text { South } \\
\text { region }\end{array}$ & $\begin{array}{c}\text { East } \\
\text { region }\end{array}$ & $\begin{array}{c}\text { West } \\
\text { region }\end{array}$ & Mean & SD & $\begin{array}{c}\text { Comparison with } \\
\text { WHO standard }\end{array}$ \\
\hline $\mathrm{pH}$ & 7.56 & 7.14 & 7.46 & 7.14 & 7.33 & 0.22 & within \\
\hline Turbidity & 3.26 & 4.92 & 3.78 & 4.92 & 4.22 & 0.84 & within \\
\hline Conductivity, $\mu \mathrm{s} / \mathrm{cm}$ & 662.0 & 540.0 & 560.0 & 540.0 & 575.50 & 58.43 & within \\
\hline Total Alkalinity, ppm & 185.0 & 205.0 & 165.0 & 198.0 & 188.25 & 17.58 & exceed \\
\hline Total Suspended Solids, ppm & 1.9 & 1.8 & 2.2 & 1.6 & 1.88 & 0.25 & exceed \\
\hline TDS, ppm & 200.0 & 360.0 & 220.0 & 260.0 & 260.00 & 71.18 & within \\
\hline DO, ppm & 7.50 & 6.98 & 6.50 & 7.98 & 6.49 & 1.59 & Medium \\
\hline BOD, ppm & 4.81 & 2.02 & 4.81 & 3.02 & 3.67 & 1.38 & Within \\
\hline COD, ppm & 14.00 & 5.60 & 12.00 & 6.60 & 9.55 & 4.09 & --- \\
\hline Total hardness, ppm & 250.0 & 278.0 & 210.0 & 228.0 & 241.50 & 29.32 & Within \\
\hline Calcium, ppm & 44.13 & 37.41 & 42.13 & 32.62 & 39.07 & 5.14 & Within \\
\hline Magnesium, ppm & 23.88 & 28.76 & 26.78 & 28.76 & 27.05 & 2.31 & Within \\
\hline Free CO, \% & 1.5 & 1.3 & 2.1 & 0.6 & 1.38 & 0.62 & within \\
\hline Chloride, ppm & 49.70 & 77.53 & 44.50 & 70.32 & 60.51 & 15.91 & -- \\
\hline
\end{tabular}

Table 7: Parameter-wise WHO standards and their WQI values of the four water bodies

\begin{tabular}{|c|l|c|c|c|c|c|c|}
\hline \multirow{2}{*}{ S. N. } & \multicolumn{1}{|c|}{ Parameters } & \multirow{2}{*}{ Units } & \multirow{2}{*}{$\begin{array}{c}\text { Units } \\
\text { weight }\end{array}$} & & \multicolumn{4}{|c|}{ Selected Water Body } \\
\cline { 5 - 8 } & & - & 0.219 & Channarayapatna & Bagur & Janivara & Anekere \\
\hline 1 & $\mathrm{pH}$ & $\mathrm{NTU}$ & & 91 & 90 & 86 & 96 \\
\hline 2 & Turbidity & $\mu \mathrm{s} / \mathrm{cm}$ & 0.371 & 36 & 82 & 70 & 76 \\
\hline 3 & Conductivity, $\mu \mathrm{s} / \mathrm{cm}$ & $\mathrm{ppm}$ & 0.0037 & 92 & 68 & 56 & 58 \\
\hline 4 & Total Suspended Solids, ppm & $\mathrm{ppm}$ & 0.0037 & 82 & 76 & 78 & 92 \\
\hline 5 & TDS, ppm & $\mathrm{ppm}$ & 0.3723 & 6 & 5 & 6 & 6 \\
\hline 6 & DO, ppm & $\mathrm{ppm}$ & 0.3723 & 66 & 72 & 64 & 76 \\
\hline 7 & BOD, ppm & $\mathrm{ppm}$ & 0.0062 & 46 & 64 & 66 & 60 \\
\hline 8 & Total hardness, ppm & $\mathrm{ppm}$ & 0.025 & 66 & 72 & 70 & 58 \\
\hline 9 & Calcium, ppm & $\mathrm{ppm}$ & 0.061 & 58 & 65 & 56 & 62 \\
\hline 10 & Magnesium, ppm & $\mathrm{ppm}$ & 0.0074 & 56 & 76 & 50 & 86 \\
\hline 11 & Chloride & & & 61.82 & 68.27 & 62.18 & 67.09 \\
\hline
\end{tabular}


Table 8: Water Quality Index (WQI) of Surface Water at Various Sampling Locations

\begin{tabular}{|c|c|c|c|c|}
\hline Karnataka region & WQI & WQI Range & & $\begin{array}{l}\text { Water Quality Indicators (Status) } \\
\text { (CCME, 2005) }\end{array}$ \\
\hline $\begin{array}{l}\mathrm{SC}_{1} \\
\text { Channarayapatna }\end{array}$ & 61.82 & \multirow{5}{*}{$\begin{array}{l}61.82-68.27 \text { (Fair to } \\
\text { marginal water quality) }\end{array}$} & $95-100$ & $\begin{array}{l}\text { Excellent: Water quality is protected with virtual absence of threat } \\
\text { or impairment; conditions very close to natural or desirable levels }\end{array}$ \\
\hline $\mathrm{SB}_{1}$ Bagur & 68.27 & & $80-94$ & $\begin{array}{l}\text { Good: Water quality is protected with only minor } \\
\text { degree of threat or impairment; conditions depart } \\
\text { from natural or desirable levels }\end{array}$ \\
\hline $\mathrm{SJ}_{1}$ Janivara & 62.18 & & $60-79$ & $\begin{array}{l}\text { Fair: Water quality is usually protected but } \\
\text { occasionally threatened or impaired; conditions } \\
\text { sometimes depart from natural or desirable levels }\end{array}$ \\
\hline \multirow[b]{2}{*}{$\mathrm{SA}_{1}$ Anekere } & \multirow[b]{2}{*}{67.09} & & $45-59$ & $\begin{array}{l}\text { Poor (Marginal): Water quality is frequently } \\
\text { threatened or impaired; conditions often depart } \\
\text { from natural or desirable levels }\end{array}$ \\
\hline & & & $0-44$ & $\begin{array}{l}\text { Very Poor: Water quality is almost always } \\
\text { threatened or impaired; conditions usually depart } \\
\text { from natural or desirable levels } \\
\text { (unsuitable for drinking) }\end{array}$ \\
\hline
\end{tabular}

Evaluation of results and grading: For each indicator, the grading scale followed the "ranking" scale recommended by the CCME (2001). That also used five categories or levels that correspond to specific levels of water quality impairment. Water quality index (WQI) of Surface water of various sampling locations of Hassan District Karnataka State ranged from 61.82 to 68.27 indicates the fair quality of water. WQI was calculated to find the suitability of water for drinking only after pretreatment like filtering, boiling, reverse osmosis and electro dialysis. An appropriate method for improving the surface water quality in the affected areas is considered for suitable treatment. WQI values ranges from 100 (excellent) to 0 (very poor). WQI scores were grouped into one of five categorized that serves to summarizes the overall state of water quality. The categories and category description are in Table 8.

\section{Conclusion}

$>$ Water quality index (WQI) of Surface water body of various Sampling locations of Channarayapatna taluka, Karnataka ranged between 61.82 and 68.27 indicates the fair quality of water. Water is suitable for drinking purposes only after pretreatment like filtering, boiling, reverse osmosis and electro dialysis.

$>$ WQI can play a big role in justifying the water pollution problems after encountered in different surface water bodies. Application of Water Quality Index (WQI) in this study has been found useful in assessing the overall quality of water and to get rid of judgment on quality of the surface water.

$>$ The analysis reveals that surface water from channarayapatna taluka of Karnataka is poor for drinking purpose as per the water quality index. However, this water can be used for drinking purpose after purification treatment followed by disinfection before consumption and it also need to be protected from the perils and contaminations and quite good for irrigation purpose.

\section{Reference}

Agbaire PO and Obi CG (2009) Seasonal Variations of Some Physico-Chemical Properties of River Ethiope Water in Abraka, Nigeria. Journal of Applied Science and Environment Management 13(1): 55 - 57.

American Public Health Association (APHA-AWWA-WPCF), (1989). Standard methods for the examination of water and wastewater, 1989.

Association of Official Analytical Chemists (AOAC) (1995) AOAC Official Methods of Analysis, 16th ed. AOAC International, Gaithersburg, Maryland, (March 1998 revision).

Bhoi DK Raj DS Mehta YM Chauhan MB and Machhar MT (2005) Physico-chemical analysis of bore wells drinking water of Nadiad territory. Asian J. Chem. 17(1): 404- 408.

Das Gupta M Purohit KM and Jayita Dutta (2001) Assessment of drinking water quality of river Brahmani. Journal of Environmental and pollution 8: 285-291. 
Guidelines for Water Quality Monitoring, Central Pollution Control Board, INDIA, MINAS/27/2007-08.

Indian Standard Specifications for Drinking Water, BIS: 10500, 1992.

Joshi JD Vora JJ Sharma SS Patel N Kothari O and Salvi K (2004) Int. J. Chem. Sci. 2(3): 337-344.

Kannan K (1991) Fundamentals of Environmental Pollution, S. Chand \& Company Ltd., New Delhi.

Ott WR (1978) Environmental Indices: Theory and Practice, Ann Arbor, MI (USA): Science Publishers Inc.

Pradhan SK, Patnaik D and Rout SP (2001) Ground Water Quality Index for ground water around a phosphatic fertilizer plant. Indian J. Env. Prot. 21(4): 355-358.

Rajmohan, N (2003) Major correlation in ground water of Kancheepuram region, South India, Indian J. Environ. Hlth. 45(1): 1-5.
Ramakrishniah CR Sadashivaiah C and Ranganna G (2009) Assessment of Water Quality Index for the Groundwater in Tumkur Taluk. E-Journal of Chemistry 6(2), 523-530. DOI: $10.1155 / 2009 / 757424$

Saha SK Naznin S and Ahmed F (2006) A Household Based Safe water intervention program for a slum area in Bangladesh. Asian journal of water, environment and pollution $3(1)$ : 21-26.

Sinha DK, Shilpi S and Ritesh S (2004) Water Quality Index for Ram Ganga river at Moradabad. Poll. Res. 23(3): 527-531.

Srivastava AK and Sinha DK (1994) Water Quality Index for river Sai at Rae Bareli for the pre-monsoon period and after the onset of monsoon. Indian Journal of Environmental Protection 14: 340-345. 